Doc. dr. Izet Terzić

\title{
Kraći osvrt na metode davetskog djelovanja
}

Sažetak

Osnovna namjera navedenog teksta jeste želja da se ukaže na neke nepravilnosti kod pojedinaca koji smatraju da ispravno govore $i$ pozivaju na ispravno islamsko učenje, dok u biti oni svojim postupcima odvraćaju ljude od islama. Navodeći kur'anske tekstove, kao $i$ hadise Allahovog Poslanika s.a.v.s. željeli smo da damo do znanja da ima osoba koje su nedovoljno upućene $u$ ispravne stavove po pitanju islamskog učenja, a kamoli da druge na to upućuju. Posljedice su katastrofalne za užu i širu zajednicu, ukoliko se ukaže prostor za pogrešno davetsko djelovanje.

Za ispravno djelovanje $i$ angažman na polju islamske dave zaista je potrebno jedno mnogo šire obrazovanje $i$ poznavanje ovog veoma specifičnog djelovanja. Naš Uzvišeni Gospodar ima devedeset $i$ devet lijepih imena / esmaul husna / među kojima su brojnija imena / svojstva koja upućuju na Njegovu blagost, milost, praštanje - od svojstava Njegovog kažnjavanja.

Isto tako Muhammed, s.a.v.s., takođe u svom poslaničkom djelovanju koristi metode blagosti u odnosu prema drugima, čime je $i$ uspio u jednoj tako veličanstvenoj misiji.

Molimo $i$ tražimo od našeg Gospodara da nas obogati svojstvima najuspješnijeg daije, podari snage na takvom djelovanju $i$ učvrsti naše noge na Pravome putu - amin.

Svjedoci smo da se Bosna i Hercegovina, kao i ostali dijelovi Balkana $\mathrm{u}$ toku posljednjih ratnih zbivanja, kao i u postratnom periodu, našla na udaru različitih razumijevanja vjere islama i prakticiranja vjerskih propisa. To je donekle i opravdana pojava zbog prisustva muslimana iz drugih podneblja koji su svojim prisustvom uveliko željeli pomoći muslimanima u najtežim trenucima. Ti ljudi su uglavnom bili pripadnici drugih fikhskih mezheba i njihovo miješanje $\mathrm{s}$ našom omladinom je rezultiralo nejasnoćama i zbunjenošću $u$ razumijevanju pojedinih vjerskih propisa. Vjerovatno je, u tom 
kontaktu s našom sredinom, nedostajalo mudrosti i primjenjivanja opće poznatih pravila u da'vetu. Trebalo je imati na umu da islam ovdje postoji više stoljeća, da je tu bilo i uleme, učenjaka, medresa i ostalih vjerskih institucija koje su čuvale i njegovale emanet vjere preuzet od njihovih prethodnika. Allahov Poslanik s.a.v.s. u jednom hadisu kaže: "Stanovnici Mekke najbolje poznaju svoje područje i svoje prilike." Tako isto i muslimani naših područja bolje poznaju naše područje, naše prilike, naše probleme, koji su se vremenom nakupili i najbolje znaju kako će ih postepeno rješavati.

Također se moralo imati na umu period različitih sistema koji su vladali ovim prostorima, pogotovo onih pedesetak godina prije rata, kada je vjera marginalizirana i stavljana u zadnji, ili, haman, nikakav plan.

Mi smo svjesni da se tokom tog teškog perioda možda uvuklo $\mathrm{u}$ vjeru nekih stvari koje nemaju neku jaku potporu u vjeri, ali ih razumijevamo kao rezultat truda na očuvanju bilo čega što ima veze $s$ vjerom, načinom očuvanja veze između ljudi i Boga, pa makar i na takav način, koji možda i nije bio najadekvatniji, ali je u tim prilikama, možda, bio jedini da bi se vjera sačuvala.

Opće je poznato pravilo da kad god neprijateljima islama i muslimana nije uspjelo da ih fizički unište i prisilno rasele, oni se okreću mnogo perfidnijoj i podmuklijoj taktici, a to je unošenje razdora među muslimane, da ih međusobno zavade i razbiju njihovo jedinstvo i slogu. Nažalost, u tome su nekad manje, nekad više i uspijevali. Tako su se pojavljivale nove stranke, nove sekte i nova tumačenja islamskih propisa, koje i danas egzistiraju među muslimanima. Njihovi pogledi i tumačenja, ponekad, ne samo da nisu bila u skladu sa glavnim izvorima naše vjere, Kur'anom i Hadisom, već je bilo i oprečnih stavova i raznoraznih novotarija koje su se uvukle $u$ propise naše vjere. Sve te nalete i pokušaje udaljavanja muslimana od glavnih izvora svoje vjere, muslimani su, hvala Bogu, $u$ najvećem broju osujetili i odbili, ostavši na kursu pravog puta i života u okrilju svoje čiste vjere.

Najnovija skupina koja se pojavila u posljednjem ratu i iza njega u Bosni i na Balkanu je prihvatila stavove drugih mezheba, ili bolje rečeno formirala svoj vlastiti mezheb, koji uveliko odudara od tradicionalnog hanefijskog mezheba, koji je ustaljen i prihvaćen 
stotinama godina na ovim prostorima. Sve to je izazvalo brojne probleme, polemike, uznemiravanja i razdor ionako krhke zajednice muslimana. Puno se o tome pisalo, pričalo, polemisalo i sukobljavalo. Tako se širila fitna i fesad među muslimanima. Po svoj prilici to je nekome i bio cilj, nekome iz redova brojnih neprijatelja muslimana, i oni su, na našu žalost, djelimično u tome i uspjeli.

Sve ovo što se dešavalo i još uvijek dešava među nama nije doprinijelo jačanju i širenju islama, ma šta ko i kako mislio, već je značio novi jaz i razilaženja među samim muslimanima, te sukobima $i$ zasad verbalnim deliktima, nažalost, čak i u džamijama.

Među ovakvim pojedincima našao se jedan broj čestitih, pobožnih i dobronamjernih mladića muslimana, koji se maksimalno pridržavaju propisa svoje vjere islama i čuvaju od harama - zabrana. Oni su upali u ovu zamku svojom naivnošću i dobronamjernošću prema svima. Oni ne znaju i nisu svjesni s kim imaju posla i ko, ustvari, iza svega toga stoji. Nisu svjesni ni posljedica koje bi se mogle desiti.

Želeći da našoj cijenjenoj omladini ukažemo da nije ispravno samo ono što im se iz takvih krugova nudi, nego da im kažemo da je naša vjera, vjera samilosti, blagosti i uzajamnog uvažavanja, jer nas je tako učio onaj koji je poslan cijelom čovječanstvu, a na čiju praksu se skoro svi pozivamo. Muhammed a.s. je poslan kao milost svjetovima i on je bio, uistinu Allahova milost, koja je hodila po Zemlji i koji je svojim riječima, između ostalog, ukazao kako se lijepim ahlakom dostižu najviše džennetske deredže.

U narednim stranicama ćemo pokušati ukazati na neka shvatanja i postupke koji nemaju opravdano uporište u našoj lijepoj vjeri, ali zato imaju kobne posljedice na jedinstvo naše muslimanske zajednice.

\section{Neklanjanje u džema’atu za postavljenim imamom}

Od pogrešnih i neispravnih shvatanja pojedinaca je da nije dozvoljeno klanjati za pojedinim imamima, ni džumu-namaz, ni ostale vaktove. Taj svoj stav oni opravdavaju tim što taj imam, po njihovom ograničenom shvatanju, ima kod sebe neke nedostatke, manjkavosti, bid'ate (novotarije) koje ga čine nedostojnim imamske dužnosti. Oni 
misle da klanjanje za takvim imamom nije ispravno i da namaz nije primljen. Kao rezultat toga imamo formiranje posebnih, odvojenih džemata, gdje oni klanjaju ,po sunnetu“, ili u istim džamijama klanjaju nakon obavljenog namaza i što je najgore, javno iznose svoje mišljenje, šireći tako smutnju i dovodeći i imama i džematlije u nezgodnu situaciju. U zadnje vrijeme je također primjetno da dženaze pojednincima, njihovim istomišljenicima, ili članovima njihovih familija, klanjaju isključivo oni, jer smatraju da su oni najbolji i najpreči da to obave, a ne dotični imam u tom mjestu, koji je postavljen od strane najviših vjerskih instanci u našoj zemlji.

Ovi ljudi ili ne znaju, ili ne žele znati, da ovakvim postupcima dovode $u$ pitanje ispravnost svog namaza i namaza onih koji se povode za njima. Toliko je hadisa u kojima Allahov Posalnik s.a.v.s. upozorava na važnost zajedničkog klanjanja, održavanja jedinstva i sloge u džematu.

$\mathrm{Ne}$ trebaju se oni brinuti za ispravnost namaza, jer je to Poslanik s.a.v.s. još davno zagarantovao džematlijama, pa čak i kada bi bilo nekih nedostataka i manjkavosti kod imama.

Imam je prvenstveno odgovoran za svoj namaz i za namaz onih koji su iza njega, jer ako on pogriješi džematlije imaju sevap i namaz im je ispravan, a imam je griješan, kao što stoji u hadisu kojeg prenosi Ebu Hurejre, r.a., koji kaže da je Poslanik, s.a.v.s., rekao:

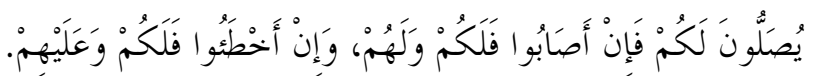

"Imami će vam klanjati pa ako to obave kako treba imaćete nagradu i vi i oni, a ako oni pogriješe vi ćete imati sevap a oni će snositi grijehe."1

S ovim se misli na klanjanje u određeno namasko vrijeme, ali i sve drugo što se tiče zajedničkog obavljanja namaza. Ibnul-Munzir kaže: „Ovaj hadis pobija mišljenje onih koji smatraju da neispravnost namaza od strane imama prelazi na one koji su klanjali za njim.“ Muhelleb kaže: „Ovaj hadis ukazuje da je dozvoljeno klanjati za bogobojaznim imamom a i za onim koji je grješnik, pogotovo ako bi se bojali njegova zla." ${ }^{2}$

\footnotetext{
${ }^{1}$ Hadis je sahih, a zabilježio ga je Buharija 2/187 (654)

${ }^{2}$ Pogledaj El-Feth 2/188.
} 
Prenosi se da je Hasan Basri upitan o klanjanju za imamom koji radi neke novotarije (bid'e) pa je Hasan rekao: „Ti za njim klanjaj, a on je odgovoran za svoju novotariju. ${ }^{6^{3}}$ Ovu predaju je Buharija spomenuo u naslovu (babu) o poglavlju klanjanja za imamom koji kod sebe ima neku novotariju.

$\mathrm{Na}$ istom mjestu Buharija bilježi da je Ubejdullah ibn Adijj ibn Hijar došao kod Osmana, r.a., kada je bio opkoljen od strane onih koji su unosili smutnju i razdor u islamskom društvu. On ga je tada upitao: „Ti si naš imam, a zapao si u situaciju u koju si već zapao, nama kao imam klanja neki čovjek koji je upleten u ovu smutnju pa se mi, klanjajući za njim nelagodno osjećamo, pa šta da radimo? Osman mu odgovori: „Namaz je najbolje nešto što ljudi mogu obavljati, pa ako ljudi čine dobro čini ga i ti s njima, a ako oni čine loše ti se kloni njihovih loših djela.“4 Ibn Hadžer kaže: „Iz ovoga vidimo da Osman nije tog imama spomenuo ni po čemu lošem, nego je rekao da je to njegovo klanjanje najbolji posao... Također, njegova izreka ukazuje na važnost zajedničkog klanjanja, pogotovo ako ima smutnji i nereda, da se džemat ne bi još više razjedinjavao. ${ }^{65}$

Ove izreke i postupci nam dovoljno govore o važnosti čuvanja džema'ta, zajedničkog klanjanja, čak ako bi i bilo nekih nedostataka kod imama.

Poznat je slučaj ashaba Ebu Seida El-Hudrij s Mervanom, Mauvinim namjesnikom u Medini, koji je htio da bajramsku hutbu održi prije klanjanja bajram-namaza, kako bi natjerao ljude da slušaju hutbu. Obzirom da slušanje hutbe nije vadžib, po mišljnju nekih učenjaka, ljudi bi se razilazili odmah nakon namaza i ne bi slušali hutbu. Ovaj namjesnik je na ovaj način htio natjerati ljude da slušaju hutbu. Ebu Seid ga je upozorio i rekao mu da je ispravno prvo klanjati

\footnotetext{
${ }^{3}$ Ovu predaju je spomenuo Buharija u Babu imameti meftun vel-mubtedi', pogledaj El-Feth 2/188 56. poglavlje u Kitabul-ezan. Ibn Hadžer kaže da je Seid ibn Mensur ovu predaju zabilježio sa svojim senedom.

${ }^{4}$ Ovo je zabilježio Buharija u svome Sahihu, babu imameti meftun vel-mubtedi', pogledaj El-Feth 2/188 (659), kitabul-ezan.

${ }^{5}$ Pogledaj El-Feth 2/188.
} 
bajram pa onda držati hutbu. Mervan se na to oglušio i uradio je onako kako je naumio. ${ }^{6}$

Također ću navesti i slučaj drugog ashaba, Velida ibn Ukbeta, Osmanovog, r.a., namjesnika u Kufi, koji se napio i tako u pijanom stanju klanjao sabah-namaz kao imam ljudima. Kada je nakon dva rekata, predao selam upitao je prisutne: "Hoćete li još koji rekat da vam dodam? Velid je bio Osmanov brat po majci i njegov namjesnik u Kufi pet godina. Kasnije su ljudi obavijestili Osmana o tom slučaju i kada je našao ko će to posvjedočiti onda je Osman naredio da se Velid izudara sa četrdeset udaraca bičem zbog tog prekršaja. ${ }^{7}$

Ove primjere sam naveo da ukažem na situacije kroz koje su sve prolazili ashabi i tabi'ini, koji su prisustvovali ovim događajim i ne kaže se da je iko od njih napustio namaz i nije klanjao za imamom, niti da je neko ponovo klanjao dotični namaz.

Kod nas se nekada zbog nebitne sitnice prigovara imamu, njegovoj akidi, o njemu se svašta priča, pa to sve uzimamo kao opravdanje da za njim ne klanjamo. Hvala Bogu, još nisam nigdje čuo da se neko od naših cijenjenih imama napio, pa u tom stanju klanjao, niti je neko pokušao da stavi hutbu prije bajram-namaza. Ako su ashabi, r.a., sve ove postupke tolerisali i za tim ljudima klanjali, želeći na taj način očuvati džema'at i zajednicu, kako mi sebi onda uzimamo za pravo da ne klanjamo za našim zvaničnim imamima.

Evo još jednog primjera gdje vidimo da su ashabi čuvali džemaat i zajednicu muslimana. Poslanik, a.s., je najavio da će doći vrijeme pa će halife kasniti sa ikindijskim namazom. Na to ga ashabi pitaju, pa kako ćemo tada postupati. On im reče: „Kod kuće klanjajte ikindiju na vrijeme, a kada zauči ezan, idite u džamiju i klanjajte skupa sa svijetom." Vidite kako se čuva jedinstvo i zajednica. Nikom od njih nije Poslanik, a.s., rekao da ne klanja za takvim imamima, niti da prekine odlaziti u džamiju, nego ih savjetuje da očuvaju zajedništvo javnog klanjanja u džamiji.

\footnotetext{
${ }^{6}$ Ovo je zabilježio Buharija u svom Sahihu, pogledaj El-Feth 2/49 (956), kitabulidejni.

${ }^{7}$ Ovaj slučaj je zabilježio Buharija, pogledaj El-Feth 7/53 (3696). 


\section{Raskoračivanje u namazu}

Safovi u namazu trebaju biti ravni, popunjeni i ne smije ostati praznina među klanjačima. Enes, r.a., prenosi da je Allahov Poslanik, s.a.v.s., rekao: „Poravnajte vaše safove, jer ja vas uistinu vidim iza svojih leđa.“ Dalje Enes, r.a., kaže: „I mi bismo doticali jedan drugog našim ramenima i našim nogama." Na kraju ove izreke u Me'merovoj predaji se dodaje i ovo: „A kada bi danas s nekim tako postupio, odmaknuo bi se od tebe kao neposlušna mazga." ${ }^{\text {" }}$

Ovaj primjer sam naveo zbog toga da vidimo koliko su ljudi još u vrijeme ashaba i tabi'ina bili osjetljivi na ovakve postupke (prislanjanja noge uz nogu isl.) pa kakva je tek situacija, sa našim svijetom danas. Moramo ljude razumjeti i ne smijemo ih ničim uznemiravati niti iritirati. Pogotovo često vidimo da pojedinci pretjerano pridaju važnost prislanjanju nogu jedne do druge, a istovremeno naprave razmak između njihovih ramena po desetak cantimetara, što je svakako pogrešno.

\section{Grubost, nasuprot umjerenosti}

Muhammed, a.s., je milost cijelom čovječanstvu i on se uistinu tako i ponašao. Njegovo ophođenje prema ljudima u sredini u kojoj je živio, bili oni muslimani ili nemuslimani, je uistinu primjer i oličenje te milosti koja je hodila zemljom. Njega su uvažavali, kako njegovi sljedbenici tako i njegovi protivnici ili neistomišljenici. Nakon tako lijepih primjera blagosti i susretljivosti sa ljudima, ko ima pravo da ovog čovjek, a.s., prikazuje kao neko strašilo, odnosno, ko sebi uzima za pravo da njegovu praksu, sunnet prikazuje svijetu kao nešto tako strašno, komplikovano ili neprihvatljivo u mnogim sredinama.

U narednim redovima nastojaćemo ukazati da je njegova praksa, sunnet, prilagodiva i primjenjiva za sva vremena i sva podnjeblja gdje žive muslimani, samo je treba istinski i pravilno razumjeti, kako bi se takva mogla i primijeniti.

\footnotetext{
${ }^{8}$ Ovo je zabilježio Buharija u svome Sahihu, pogledaj El-Feth 2/211 (725), kitabulezan.
} 
Poslanik, a.s., je za sebe rekao: „Ja sam milost koja vam je poklonjena.““9 „Poslan sam s milošću.“" ${ }^{10}$ Dalje Poslanik savjetuje, pa kaže: „Smilujte se drugima pa će se i vama smilovati!“611 „Allah me nije poslao s poteškoćama niti naporima, nego me poslao kao učitelja i onoga koji će olakšavati."“12

Poslanik je bio blag i milostiv i brinuo se za svoje sljedbenike. Allah, dž.š., za njega kaže: „Došao vam je Poslanik, ...a prema vjernicima je blag i milostiv. “' ${ }^{13}$ Njemu njegov Gospodar ukazuje da je bio drukčiji i ishod njegove misije bio bio drukčiji: „Samo Allahovom milošću ti si blag prema njima; a da si osoran i grub, razbježali bi se iz tvoje blizine. Zato im praštaj i moli se da im bude oprošteno i dogovaraj se s njima. “14 Također, ga Allah upućuje pa kaže: „Ti sa svakim - lijepo! i traži da se čine dobra djela, a neznalica se kloni! ‘15

Pa gdje smo mi od ovih kur'anskih uputa, gdje smo od Poslanikove prakse?!

Blagost je osobina kojom se treba krasiti svaki musliman, a onaj koji poziva u vjeru pogotovo. To je osobina koja sva druga djela krasi, a njen gubitak sve ostalo kvari. Na to nas upućuje Allahov Poslanik, a.s., pa kaže: „Blagost u čemu god se nađe, ona to ukrasi, a gdje god je nema to je pokvareno. ${ }^{16}$ Poslanik, a.s., poziva svoje sljedbenike ovoj osobini pa kaže: „Zaista je Allah Blag i voli blagost, i On za blagost daje ono što ne daje za grubost, niti za bilo što mimo toga. ${ }^{\text {17 }}$

Poslanik, a.s., je bio najblaže naravi i najmilostiviji prema ljudima. Tako ga je Allah, dž.š., odgojio.

Poznat je slučaj beduina koji je učinio malu nuždu u džamiji, kako ga je Poslanik zaštitio od ashaba svojom blagošću, a ashabima je

\footnotetext{
${ }^{9}$ Hadis je zabilježio Hakim.

${ }^{10}$ Hadis je zabilježio Muslim.

${ }^{11}$ Hadis je zabilježio Ahmed.

${ }^{12}$ Hadis je zabilježio Muslim.

${ }^{13}$ Sura Et-Tevbe, 128.

${ }^{14}$ Sura Al Imran, 159.

${ }^{15}$ Sura El-E'araf, 199.

${ }^{16}$ Hadis je zabilježio Muslim.

${ }^{17}$ Hadis je zabilježio Muslim. 
nakon toga rekao: „Vi ste poslani da olakšavate, a niste poslani da otežavate. ${ }^{618}$

Upečatljiv je primjer Poslanikovog pedagoškog pristupa mladiću koji od njega traži da mu dozvoli da čini zinaluk, pa ga on lijepo savjetuje i na kraju stavlja ruku na njegove grudi i moli Allaha, dž.š., ovom dovom: „Allahu moj, oprosti njegove grijehe, očisti njegovo srce i učini ga moralnim!"“ Nakon toga ovaj mladić nije više ni pomišljao o nemoralu. ${ }^{19}$

$\mathrm{Na}$ nama je da se upitamo kako bismo mi postupili da se $\mathrm{u}$ našem drušvu desilo da neko učini nuždu u džamiji i tome slično, kakva bi bila naša reakcija i bismo li tada oponašali Poslanika?

Poslanik, a.s., je čak učio dovu za one koji su samilosni prema ljudima, pa u jednom hadisu stoji da je ovako učio: „Allahu moj, ko god bude nadređen ljudima iz moga ummeta pa bude prema njima milostiv i Ti se njemu smiluj!‘ 20

U islamu nema zastranjivanja, pretjerivanja, nema bježanja ni u jednu krajnost. Mi smo zajednica srednjeg puta i kao takve nas je Allah, dž.š., u Kur'anu opisao: „ummeten vesetan““21 ummet sredine, koji se također može prevesti i kao umjeren, prosječan, osrednji i tome slično. Ibn Kesir ovu riječ „vesetan“ objašnjava kao: „najbolji i najplemenitiji“" Prema tome, svako zastranjivanje u vjeri (guluvv), značilo bi skretanja s ovog ispravnog, srednjeg puta na koji nas je Muhammed, a.s., izveo.

„Spomeni, u Knjizi, Ibrahima! On je bio istinoljubiv vjerovjesnik. Kada je rekao svom ocu: „O oče moj, zašto se klanjaš onome koji niti čuje niti vidi, niti ti može od ikakve koristi biti? O oče moj, meni dolazi znanje, a ne tebi; zato mene slijedi, i ja ću te na pravi put uputiti; o oče moj, ne klanjaj se šejtanu, šejtan je Milostivome uvijek neposlušan; o oče moj, bojim se da te od Milostivog ne stigne kazna, pa da budeš šejtanu dug“, otac njegov je rekao: ,Zar ti mrziš božanstva moja, o Ibrahime? Ako se ne okaniš, zbilja ću te kamenjem

\footnotetext{
${ }^{18}$ Hadis je zabilježio Buharija.

${ }^{19}$ Hadis je zabilježio Ahmed.

${ }^{20}$ Hadis je zabilježio Muslim.

${ }^{21}$ Sura El-Bekare, 143.
} 
potjerati, zato me za dugo vremena napusti!“ „Mir tebi!“ - reče Ibrahim. „Moliću Gospodara svoga da ti oprosti, jer On je vrlo dobar prema meni “. ${ }^{22}$

Gore navedeni ajeti nam ukazuju na jedan veoma važan odnos roditelja i djeteta (oca i sina), a koji se nalazi na krajnje suprotnim ideološkim stavovima. Riječ je o Ibrahimu, a.s., jednom od najvećih i najznačajnijih poslanika u sve tri monoteističke religije. Ponekad se i kaže da su svi sljedbenici knjige Abrahamovi potomci jedinstveni u poštovanju ovako velike ličnosti.

Citiranje ovih ajeta ima za cilj da se ukaže na jednu takvu ljudsku veličinu Božijeg poslanika kakav je bio Ibrahim, a.s., jer, osim Muhammeda, a.s., jedino se još za Ibrahima, a.s., poimence u Kur'anu eksplicite kaže da je uzor drugima. Pa šta bismo sve mogli navesti kao korisne poruke iz dijaloga čistog monoteiste Ibrahima, a.s., i njegovog oca velikog krivovjernika, idolopoklonika?!

- Neobičnost i veličina u metodi ophođenja svejsnog sina, punog odgoja, pažnje i ljubavi prema svome ocu

- U četiri navrata, u četiri ajeta oslovlja ga sa toplim riječima (ja ebeti) „Babuka moj“, a nakon toga mu kazuje na pogreške koje je kod njega primijetio.

- Iznosi mu jasne razumske i logične dokaze smirenim tonom, a ne grubim i oštrim jezikom.

- Svoje primjedbe na očeve pogreške konstatuje sa žalom i tugom, ukoliko ih ne prihvati.

- Očev odgovor na prijatne riječi sina Ibrahima, a.s., je bio pun grubosti i oholosti, bez imalo očinske ljubavi prema svom djetetu.

- Nakon bezuspješnog pozivanja i grubog odbijanja Ibrahim, a.s., i dalje gaji ljubav prema ocu koju iskazuje molbom Stvoritelju da mu dopusti da učini dovu (moli za oprost svome ocu).

- Jedan određen period je Ibrahim, a.s., imao dozvolu da moli za oca mušrika, krivovjernika, a onda mu je Uzvišeni Allah to zabranio.

${ }^{22}$ Sura Merjem, 40-47. 
Trajna poruka iz citiranih ajeta je također i zabrana da se diže glas na roditelje, a kamoli da budu fizički napadnuti od svoje djece.

Nažalost, naši mediji svojim „crnim hronikama“ donesu ponekad žalosne vijesti kako djeca tuku, maltretiraju, ili čak ubijaju svoje roditelje.

\section{Umjerenost u svakodnevnim poslovima}

Kada pogledamo život našeg uzora Muhammeda, s.a.v.s., vidimo da je on u svemu bio umjeren, u jelu i piću, jer je prakticirao kur'anski ajet: „Jedite i pijte, samo ne pretjerujte; On ne voli one koji pretjeruju.“23 Također je Poslanik bio umjeren u smijanju. „Poslanik se nikada ne bi (glasno, grohotom) smijao, već bi se smiješio.“24 Poslanik upućuje na umjerenost u tome pa kaže: „Nemoj se puno (neumjereno) smijati, jer pretjeran smijeh umrtvljuje srce. ${ }^{625}$ Poslanik, kao naš uzor je bio umjeren u svemu, u ibadetu, u da'vetu, držanju govora, dužini učenja $\mathrm{u}$ namazu $\mathrm{i}$ na to je podsticao one koji ga slijede.

Dr. Jusuf El-Karadavi, navodeći osobenosti naše, islamske kulture spominje i karakterisiku srednjeg puta ili umjerenosti, te pojašnjava da se na taj način ona izdiže iznad lijevih i desnih ekstrema drugih zajednica. ${ }^{26}$

\section{Osjećaj za sredinu u kojoj se nalazimo}

Onaj ko poziva u vjeru, ili pojašnjava neke vjerske propise, uvijek mora imati u vidu gdje se nalazi, kome se obraća i da li je ta skupina $\mathrm{s}$ kojom on razgovara $\mathrm{u}$ stanju razumjeti njegov govor, odnosno, da li je to o čemu govorimo odgovarajuća i najvažnija tema o kojoj u toj sredini treba govoriti. Ako ne budemo imali sluha i osjećaja za sredinu u kojoj se nalazimo, možemo postići potpuno suprotan efekat od onoga koji smo željeli. Poslušajmo izreke nekih ashaba koji nas na to upozoravaju.

\footnotetext{
${ }^{23}$ Sura El-E'araf, 31.

${ }^{24}$ Hadis je zabilježio Tirmizi u Eš-Šemailu.

${ }^{25}$ Hadis je zabilježio Tirmizi.

${ }^{26}$ Pogledaj Suvremeni prikaz Poslanikove ličnosti, S. Indžić, str. 10.
} 

se reći.“"

Ebu Derda', r.a., kaže: „Na svakom mjestu treba znati šta će

Alija, r.a., kaže: „Ljudima govorite onoliko koliko su oni u stanju da razumiju, zar želite da oni zaniječu vjeru u Allaha i Njegovog Poslanika.“"

Ibn Mes'ud, r.a., kaže: „Kada god ljudima pričaš nešto što njihovi umovi ne mogu razumjeti, taj govor će neke od njih odvesti u iskušenje (smutnju ili zabunu). ${ }^{627}$

Pogledajmo kako Poslanik upozorava Muaza na sredinu u koju će doći i kako ga upućuje kako će se ponašati: Šalje ga u Jemen i upozorava ga da se drži postepenosti u pojašnjavanju vjerskih propisa, pa mu kaže: „Zaista ćeš ti doći među ljude kojima je već ranije objavljena nebeska knjiga, pa ih pozovi da priznaju da je samo Allah Bog i da je Muhammed Njegov poslanik. Ako oni od tebe to prihvate, onda ih upoznaj da im je Allah propisao pet namaza dnevno. Ako od tebe to prihvate, onda ih obavijesti da im je Allah propisao zekat, koji bogati daju siromašnim. Ako to prihvate, onda se čuvaj da uzimaš ono što je najkvalitetnije od njihovih imetaka i boj se dove onoga kome je učinjena nepravda, jer između nje i Allaha nema prepreke."28

\section{Umjerenost u dužini učenja u namazu}

Kada čovjek klanja sam može da uči koliko hoće dugo, ali na to ne smije druge ljude prisiljavati. Poznat je slučaj kada je Poslanik klanjao teravih-namaz pa su se ljudi narednih noći počeli sve više i više sakupljati i povoditi za njegovim namazom. Nakon toga on nije nikako izašao klanjati i rekao je: "Vidio sam šta ste uradili pa nisam htio više izlaziti klanjati, jer sam se pobojao da vam se to ne propiše kao obavezan namaz, a vi to ne budete mogli izdržati.",29

U pouzdanim hadisima preneseno je da se Poslanik, s.a.v.s., naljutio na neke ashabe koji su predvodili džemat zbog toga što su previše dugo učili poslije El-Fatihe kao što je to bilo sa Muaz ibn Džebelom i Ubej ibn Kabom, r.a.

\footnotetext{
${ }^{27}$ Predgovor Muslimovog Sahiha.

${ }^{28}$ Hadis je zabilježio Muslim.

${ }^{29}$ Hadis su zabilježili Buharija, Muslim i drugi. 
Neki čovjek se požalio Poslaniku, s.a.v.s., da ne može prisustvovati sabah-namazu zbog toga što imam previše dugo uči. Tada je Poslanik rekao:

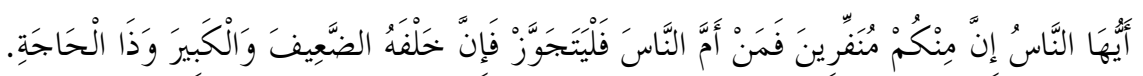

"O ljudi zaista među vama ima onih koji razgone džemat. Ko od vas bude imam ljudima neka bude umjeren u učenju Kur'ana, jer zaista iza vas ima slabih, starih i ljudi sa potrebama.,"30

Poslanik, s.a.v.s., upozorava da se ne smije puno otezati sa namazom pogotovo, kada je neko imam drugim ljudima. $\mathrm{Na}$ to ukazuje slijedeći hadis:

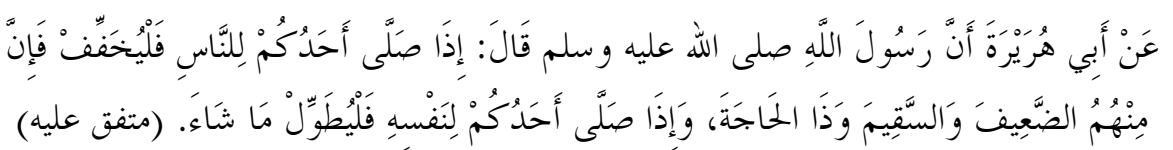

Ebu Hurejre, r.a., pripovijeda da je Allahov Poslanik, s.a.v.s., rekao:

„Kada neko od vas klanja kao imam ljudima neka bude umjeren u namazu, jer zaista među njima ima slabih, bolesnih i ljudi sa potrebama, a kada neko od vas klanja samo za sebe, onda neka odulji koliko hoće. “61

U ovom hadisu Allahov Poslanik, s.a.v.s., traži od imama, koji predvode namaz da budu umjereni u učenju, nakon sure El-Fatiha znajući da iza njih ima slabih, bolesnih, starih, nemoćnih, žena trudnica ili dojilja, putnika i drugih osoba s različitim potrebama ili ograničenjima.

Umjerenost pri učenju u namazu podrazumjeva to da se ne uči previše dugo poslije El-Fatihe te da se ruku' i sedžda ne otežu više nego što treba. Sa ovim se ne misli na momenat povratka sa ruku'a niti na sjedenje između dvije sedžde. Upravo radi toga Buharija je ovom hadisu stavio ovakav naslov: "Poglavlje u kojem se govori o umjerenosti imama na kijamu i potpunom izvršavanju ruku'a i sedžde.”

\footnotetext{
${ }^{30}$ Hadis je sahih, a zabilježio ga je Buharija 2/200 (704)

${ }^{31}$ Hadis bilježe Buharija i Muslim
} 
Jednom prilikom se desilo da je Muaz, r.a., počeo na jaciji namazu učiti suru El-Bekare. Tada je jedan ashab napustio zajedničko klanjanje, klanjao sam za sebe i otišao kući. Neki ljudi su za njega rekli da je munafik, a on se požalio Poslaniku, s.a.v.s., i rekao: "Poslaniče, ja cijeli dan radim sa svojim devama, a Muaz je došao i počeo dugu suru u namazu." Tada je Poslanik pozvao Muaza i rekao $\mathrm{mu}:$

\section{يَا مُعَاَذ أَفَتَّانْ أنْتَ....}

“O Muaze, zar hoćeš da posiješ smutnju među muslimanima?"32 Što znači: Zar ćeš ti ljude razgoniti i odvraćati od vjere. Tada ga je posavjetovao da uči suru Eš-Šems ili Ed-Duha ili ElE'ala.

Allahov Poslanik, s.a.v.s., vodio je računa o onima koji su klanjali za njim pa bi nekada skratio učenje iza Fatihe i učinio bi namaz umjerenim.

Ebu Katade, r.a., prenosi da je Allahov Poslanik, s.a.v.s., rekao:

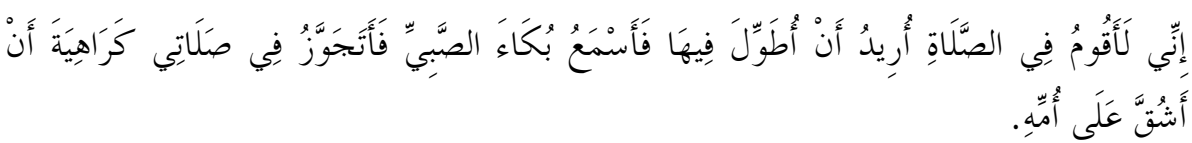

"Zaista ponekad počnem da klanjam namaz i želim da duže učim, ali kad čujem plač djeteta onda skratim učenje u namazu ne želeći da činim poteškoću njegovoj majci."

Treba napomenuti da se mora voditi računa o ispravnom izvršavanju namaskih ruknova i skrušenosti u namazu kako ova umjerenost ne bi dovela do kvarenja namaza pa da ne budemo od onih koji klanjaju namaz, a namaz im se ne prima, jer je namaz ono za što ćemo prvo biti pitani na Sudnjem danu.

Poslanikova tolerancija je dosegla do te mjere da bi on dozvolio da ga njegov unuk, za vrijeme boravka na sedždi zajaše, pa se on ne bi vraćao sa sedžde sve dok on sam ne siđe. Kada su ga ashabi upitali o razlogu njegovog oduljivanja sa sedždom on je rekao:

\footnotetext{
${ }^{32}$ Hadis je sahih, a zabilježio ga je Buharija 2/200 (705)

${ }^{33}$ Hadis je sahih, a zabilježio ga je Buharija 2/201 (706) 
"Moj unuk me zajahao dok sam bio na sedždi, pa nisam htio da ga ometam sve dok on sam nije sišao."

Upitajmo sebe, kako bi se mi ponašali, ili kako se ponašamo kada nam se dijete samo primakne dok smo u namazu, a da ne govorimo o tome kada bi nam sjelo na leđa?!

U drugom slučaju Poslanik drži svoju unukicu u rukama dok klanja, pa kada ode na sedždu spusti je na zemlju, a kada se vrati sa sedžde, ponovo je uzme u naručje.

\section{Naređivanje dobra i odvraćanje od zla}

Među najvećim greškama koje se prave su greške u pozivanju u vjeru. Pravilo je da, ako će pokušaj izmjene nekog postupka dovesti do situacije gore nego što je bila, onda je bolje da se u to ne dira. Od najboljih primjera za to je ovaj Poslanikov hadis, u kojem se on obraća Aiši, r.a.: „O Aiša, da tvoj narod nije blizu džahilijetskog vremena, ja bih naredio da se Kaba poruši, pa bih izgradio na njoj ono što je uklonjeno. Vratio bih njen ulaz na visinu zemlje, napravio na njoj dvoja vrata, istočna i zapadna, i vratio bih je na Ibrahimove, a.s., temelje." 34

O načinu obraćanja ljudima govori nam i kur'anski ajet $u$ kojem Allah, dž.š., naređuje Musa'u i Harunu da odu Faraonu, koji se uzoholio i za sebe rekao da je bog: „Idite Faraonu, on se uistinu osilio PA MU SE BLAGIM GOVOROM OBRATITE ne bi li se pobojao i podsjetio." 35 Kada Allah naređuje svome poslaniku da se ovom oholim i obijesnom čovjeku blago obrate, kako onda mi treba da se obraćamo našem narodu, koji želi nešto da nauči, ali da mu se to na lijepo način objasni.

U komentaru ovog ajeta pojedini učenjaci spominju slučaj jednog čovjeka koji je bio previše grub u svom nastupu, pa je ušao kod tadašnjeg halife i počeo galamiti, ukazujući mu na nedostatke $\mathrm{i}$ tešku situaciju u društvu. Tada ga mudri halifa podsjeti na gore spomenuti ajet i reče mu: "Ti znaš kako je Allah rekao Musau da se

\footnotetext{
${ }^{34}$ Hadis su zabilježili Buharija, Muslim, Nesai i Ahmed.

${ }^{35}$ Sura Ta ha, 43-44.
} 
obrati Faraonu, pa niti sam ja gori od Faraona, a nisi ni ti bolji od Musa'a, molim te da se udostojiš i da lijepo kažeš što želišs!"

Od primjera koji ukazuju da treba uvažavati starije i čuvati da se njihovi osjećaji ne povrijede je slučaj kada su Poslanikovi unuci, Hasan i Husejn, vidjeli nekog starijeg čovjeka koji nije znao ispravno uzeti abdest. Tada su mu se mudro obratili: "Amidža, ako ti nije teško da ocijeniš ko od nas dvojice ispravnije uzima abdest? Kada je čovjek vidio kako oni to lijepo rade, sam u sebi je rekao: "Ne zna se ko od vas dvojice to ljepše obavlja, ali ono kako to ja radim uistinu ne valja." Na taj način je poruka stigla onome kome treba, a niko se nije našao uvrijeđen.

\section{Neki smatraju da je najveći iman izabrati ono što je najteže}

Pojedini ljudi smatraju da je najbolje izabrati ono što je najteže u vjeri. Oni misle da tako zadobijaju najveću nagradu. Svakako da je to zabranjeno činiti i čovjek ne smije sebi otežavati ono što mu je Allah olakšao.

Enes, r.a., kaže da je Poslanik, s.a.v.s., rekao: „Nemojte sebi otežavati pa da vam i Allah onda oteža. Zaista su ljudi prije vas sebi otežali pa im je Allah još otežao..." ${ }^{36}$

Naredni tekstovi ukazuju da to nije bila Poslanikova praksa, jer Allah od svojih robova na traži da se muče i vjera nije zbog toga poslana.

Aiša, r.a., kaže: “Kad god je Poslanik, a.s., imao prilike da izabere između dvije stvari, uvijek bi izabrao ono što je lakše, ako u tome ne bi bio grijeh, a ako bi tu bio grijeh onda bi bio najdalje od te stvari." 37

Allah, dž.š., u Kur'anu kaže: “Ta - ha. Ne objavljujemo Kur'an da se mučiš, već da bude pouka onome ko se boji." 38

„I sve što je dobro Mi ćemo tebi olakšati. “639

\footnotetext{
${ }^{36}$ Ebu Davud (4904) i Ebu Je'ala (3694).

${ }^{37}$ Hadis je muttefekun alejhi.

${ }^{38}$ Sura Ta-ha, 1-3.

${ }^{39}$ Sura El-E'ala, 8.
} 
Ibn Kesir ovo pojašnjava ovako: "Sva dobra djela ćemo ti olakšati, propisat ćemo ti lahku, blagu i umjerenu vjeru u kojoj nema iskrivljivanja, niti nelagodnosti niti poteškoće."

Allah, dž.š., također kaže: "Allah želi da vam olakša, a ne da poteškoće imate. $" 40$

Poslanikova praksa, kao i savjet njegovim izaslanicima je uvijek bio: "Olakšavajte i nemojte otežavati, obveseljavajte i obradujte ljude i nemojte ih od sebe razgoniti!" 41

Već smo spomenuli hadis u kojem Poslanik upozorava svoje ashabe i kaže im: „,Vi ste poslani da olakšavate, a niste poslani da otežavate. ${ }^{642}$

Pogledajmo šta nam Poslanik, a.s., kaže:

"Najdraža Allahu vjera je ona koja je blaga i lahka."

„Ova vjera je lahka i neće se niko natjecati sa njom, a da ga ona neće nadjačati, pa budite umjereni i zbližavajte." ${ }^{44}$

„Zaista je ova vjera jaka pa u nju ulazite s blagošću, jer onaj koji previše brzo tjera svoju jahalicu (pretjerava u vjeri) niti će stići tamo gdje je krenuo niti će mu jahalica ostati u životu. ${ }^{645}$

Poslanik upućuje na olakšicu skraćivanja namaza na putu i u drugim situacijama i za tu olakšicu kaže: „,To vam je sadaka, koju vam je dao Allah pa primite sadaku od Njega.“‘6

Enes, r.a., pripovijeda da je Poslanik vidio nekog čovjeka kako ide pješice oslanjajući se na dvojicu ljudi oko sebe. Kada je upitao za njega, rekoše mu da se on Bogu zarekao da će pješačiti. Tada mu Poslanik naredi da uzjaše jahalicu i reče: „Zaista Allahu ne treba ovo što taj čovjek sam sebe kažnjava. “47

\footnotetext{
${ }^{40}$ Sura El-Bekare, 185.

${ }^{41}$ Hadis je muttefekun alejhi.

${ }^{42}$ Hadis je zabilježio Buharija.

${ }^{43}$ Buharija -te'alikan- i u El-Edebul-mufredu str. 109.

${ }^{44}$ Hadis je zabilježio Buharija.

${ }^{45}$ Ahmed i Bezzar.

${ }^{46}$ Hadis su zabilježili autori šest najpoznatijih hadiskih zbirki.

${ }^{47}$ Buharija, 6/177, kitabul-ejman i Muslim, 3/1264.
} 
Jednom prilikom, dok je Poslanik držao hutbu, ugledao je nekog čovjeka kako stoji izložen suncu. Upitao je za njega, pa mu odgovoriše da je to čovjek zvani Ebu Isra'il, koji se zarekao da će postiti i tako stajati, neće nikako sjedati, niti će ići u hladovinu, niti će s kim razgovarati. Tada Poslanik reče: „Recite mu neka razgovara, neka sjedne u hlad i neka dovrši svoj post.““48

Ukbe ibn Amir, r.a., kaže da se njegova sestra zarekla da će do Kabe otići pješice, bosa, pa mi je rekla da o tome upitam Poslanika, pa kada sam ga upitao on mi reče: „Neka malo pješači pa onda neka uzjaše na jahalicu. “49

Iz ovih hadisa se razumije da namjerno paćenje i izlaganje poteškoći nema nikakve veze sa lahkoćom ove vjere i njenom blagošću.

Imam El-Izz ibn Abdusselam kaže: „Nije ispravno činiti ibadet sa poteškoćama, jer ibadet u sebi sadrži veličanje Allaha, dž.š., a patnja nije ni veličanje ni poštivanje. ${ }^{\text {“50 }}$

Ibn Hadžer kaže: „Ovo ukazuje da sve ono što šteti čovjeku i nanosi bol nije vjerom propisano, niti ima potporu u Kur'anu, niti u Sunnetu, kao što je izloženost suncu, hodanje pješice bez obuće i tome slično."

Ibn Tejmije kaže: „Ako neko sam sebe, beskorisno, kažnjava i nanosi bol, to nema nikakve veze sa našom vjerom, jer nam je Allah naredio ono što nam koristi a zabranio nam je ono što nam šteti. “51

Jednom prilikom je Poslanik ušao u džamiju pa je ugledao konopac vezan između dva stupa. Kada je upitao za što ovo služi, ashabi su mu odgovorili da to jedna žena koristi kada klanja noćni namaz pa joj se zadrijema, onda se ona uhvati za taj konopac da ne padne. Tada je on naredio da se to makne.

Poslanička preporuka je, da onaj ko je pospan, u tom stanju ne treba da klanja nafile, da ne bi dove pogrešno učio.

\footnotetext{
${ }^{48}$ Buharija, 6/177, kitabul-ejman i Ebu Davud.

${ }^{49}$ Buharija, 3/35, kitabul-hadž i Muslim, 3/1264.

${ }^{50}$ Kavaidul-ahkam, 1/36.

${ }^{51}$ El-Fetava, 22/314.
} 
U ovakvim prilikama bi Poslanik rekao: „Izvršavajte od ibadeta ono što možete, jer zaista Allahu neće dojaditi da vas nagrađuje sve dok vama ne dojadi da činite dobra djela.“

\section{Različitost među ashabima je postojala}

Ashabi su najodabranija generacija koju je Allah odabrao da budu društvo Poslaniku, s.a.v.s. Međutim, i oni su se razlikovali po svojim osobinama i specifičnostima. Neki od njih su se istakli u nekoj oblasti, drugi opet u drugoj $\mathrm{i}$ to je normalna pojava. Također su se razlikovali po svojoj privrženosti vjeri, posvećenosti nekoj vrsti ibadeta. Neki su se više družili sa Poslanikom, a drugi su imali drukčije radne obaveze.

Kod islamskih učenjaka poznata je strogost Abdullaha ibn Omera i popustljivost Abdullaha ibn Abbasa.

Ako je već postojala različitost i kod ashaba, pa ona mora postojati i kod našeg naroda. Ne mogu svi ljudi biti na istoj deredži privrženosti i mi toga moramo biti svjesni.

Poslanik ističe posebnosti nekih od svojih drugova, pa kaže: „Najmilostiviji od mog ummeta je Ebu Bekr, najstrožiji u vjeri Omer, najiskreniji u stidljivosti je Osman, najbolje poznaje halal i haram Muaz, najbolje poznaje nasljedno pravo Zejd i svaki narod je imao svoga povjerenika, a povjerenik moga ummeta je Ebu Ubejde ibn ElDžerrah. “52

Poznat je primjer Abdullaha ibn Amra, r.a., koji traži od Poslanika da mu dozvoli da što više vremena provede u dobrovoljnom postu, noćnom namazu, da što više puta prouči Kur'an i tome slično. Poslanik ga savjetuje da se ne opterećuje i nakon njegove upornosti on mu kaže da posti svaki drugi dan i nema bolje od toga. Kada je Abdullah ušao $u$ godine $i$ nije više $s$ lahkoćom mogao izvršavati preuzete obaveze, koje nije htio sada da napusti, onda je rekao: „Kamo sreće da sam prihvatio od Poslanika olakšicu koju mi je nudio. ${ }^{63}$ Kasnije je sam Abdullah priznao da je sebe opteretio, pa mu je to Allah teškim učinio.

\footnotetext{
${ }^{52}$ Hadis je sahih, Ahmed, Tirmizi, Ibn Madže i drugi.

${ }^{53}$ Buharija i Ebu Davud.
} 
Nasuprot ovom spomenutom primjeru navedimo slučaj ashaba koji se interesuje samo za farzove, pa i za njega Poslanik obećava Džennet.

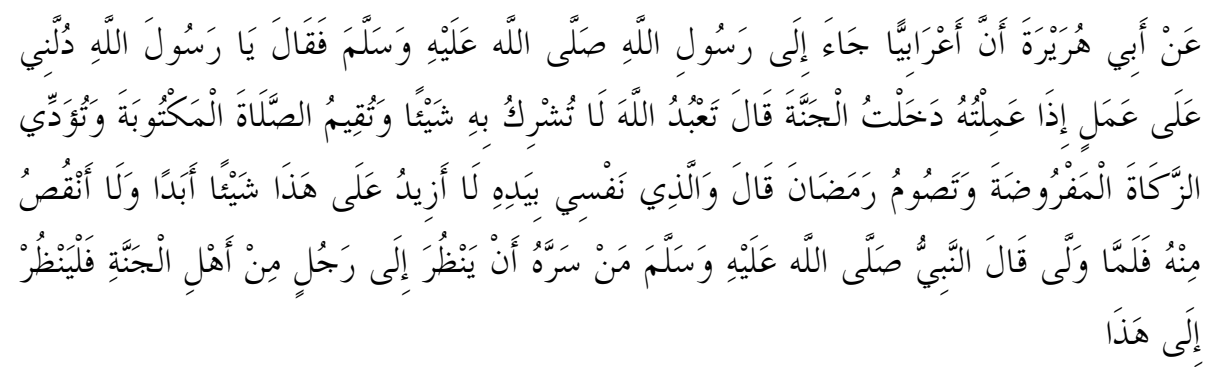

Ebu Hurejre, r.a., kaže da je neki beduin došao Poslaniku, s.a.v.s., i rekao: "Allahov Poslaniče, uputi me na djelo za koje ću, ako ga budem radio, ući u Džennet." On mu je rekao: “Obožavaj Allaha i nemoj $\mathrm{Mu}$ pripisivati druga, klanjaj propisane namaze, daji obavezni zekat i posti mjesec ramazan." "Tako mi onoga u čijoj ruci je moj život - reče beduin- neću ovome ništa dodavati, niti ću šta od toga oduzimati.»

Kada je on otišao, Poslanik, s.a.v.s., je rekao: «Ko želi da vidi čovjeka iz Dženneta, neka pogleda u ovoga čovjeka.» ${ }^{54}$

U vrijeme Poslanikovog života desilo se nekoliko slučajeva kršenja vjerskih propisa od strane ashaba, pa i pored toga je Poslanik s njima fino razgovarao, nije dozvoljavao da se s njima neko ismijava, nego se prema njima korektno odnosio.

Dok je jedan ashab bio bičevan i udaran zbog ponovnog pijenja alkohola, neko od prisutnih reče: „Allah te ponizio! Poslanik na to reče: „Nemojte biti pomoćnici šejtanu protiv svoga brata!6655

Kada je htio da klanja dženazu-namaz ženi koja je nakon činjenja zinaluka kamenovana, neko od ashaba reče, pa zar ćeš njoj klanjati dženazu? Tada Poslanik reče: „Ona se uistinu pokajala tako jakom tevbom, kada bi se razdijelila na sve stanovnike Medine, svima bi doteklo.“

Poslaniku se navodi primjer pobožne žene koja danju posti, a noću klanja. On na to kaže da će ona u Džehennem zato što bi noću

\footnotetext{
${ }^{54}$ Hadis su zabilježili Ebu Davud 13/156 (4776), Tirmizi 6/128 (2061) i drugi.

${ }^{55}$ Buharija, 8/197, kitabul-hudud.
} 
obilazila komšinska vrata, prisluškivala njihov razgovor i prenoseći tuđe riječi zavađala komšije. Također Poslanik upozorava da će jedna žena u Džehennem zato što je zatvorila mačku i nije joj dala ni hranu ni piće. Nasuprot tome navodi slučaj žene, koja je činila zinaluk, pa je napojila žednog psa i biće joj oprošteno.

Pogledajmo Poslanikov način podučavanja ashaba i ukazivanja na greške. Muavija ibn Hakem, r.a., priča: „Jednom prilikom dok sam klanjao sa Poslanikom jedan čovjek je kihnuo pa sam mu ja u namazu rekao: „Jerhamukellah.“ Prisutni su me presjekli svojim oštrim pogledima. Ja sam tada rekao: „Teško mojoj majci, što me tako gledate? Tada su mi oni svojim rukama pokazali da šutim, pa sam ušutio. Kada je Poslanik završio s namazom, draži mi je i od oca i majke, ja nisam vidio boljeg i pažljivijeg pedagoga i učitelja od njega. Tako mi Allaha, niti me je kritikovao, niti me udario, niti mi je šta ružno rekao, nego mi je na lijep način rekao: „Zaista u namazu ne priliči da se išta govori, osim Subhanellah, Elhamdulilla i učenja Kur'ana."56

\section{Zaključak}

Vrijeme i događaji nas potiču da reagujemo na neke pojave oko nas, a prethodno navedeni tekst je jedan skroman doprinos ukazivanju šta je u skladu sa zdravim razumom, a šta nije - kada govorimo o da'vetskim aktivnostima.

Dva osnovna islamska izvora, Kur'an i Hadis ne dozvoljavaju nam da iskačemo iz njihovih okvira prilikom pozivanja na Pravi put. Džehalet - neznanje je velika opasnost na poljima bilo koje naučne discipline, a u gore navedenim događajima, bili smo i svjedoci tragičnih, smrtnih, posljedica.

Ovim tekstom sam želio makar malo baciti svjetla na ispravno korištenje da'vetskih metoda, kao i na pogrešno razumijevanje istih. Uzimajući pouku i od jednih i od drugih razumom obdareni će znati prepoznati i primijeniti ispravne metode u svom djelovanju. A naš Gospodar na više mjesta u Kur'anu kaže da Svoje znakove, dokaze, upravo i nudi onima koji pameti imaju.

\footnotetext{
${ }^{56}$ Muslim,1/381, kitabul-mesadžid.
} 
I na kraju molim Uzvišenog Allaha da naša djela učini da budu samo u ime Njega, da naši postupci budu onakvi kakve On voli, da naše ponašanje, prakticiranje vjerskih propisa, pozivanje drugih $u$ vjeru, bude na najljepši način i da bude u skladu sa onim kako je to činio Muahmmed, s.a.v.s., (amin).

\section{Literatura:}

1. Kur'an, a.š.

2. Hadiske zbirke

3. El-Gazali, Ebu-Hamid, Ihja'u ulumid-din, Bookline, Sarajevo, 2007.

4. El-Askalani Ibn Hadžer, Fethul-Bari, Darur-rejjan lit-turas, Kairo, 1987., drugo izdanje

5. Atijje Izzet, El-Bid'a, Darul-kitab el-arebi, Bejrut, 1980.

6. Sandžaki Ebu-Muhammed, Može li se opravdati neznanjem u djelima velikog širka i jasnog kufra?, Plav, 2002.

7. El-Hanbeli Ibn Redžeb, Džami'ul-ulumi vel-hikem, Muesseseur-risala, Bejrut, 1995, šesto izdanje. 
DOC.DR.IZET TERZIĆ, SENIOR LUCTURER

\section{A BRIEF RESTROSPECTION OF METHODS IN DA'WAH ACTVITY}

SUMMARY

Basic intention of this article is to indicate several irregularities present in the activity of individuals who are convinced that they are calling to correct Islamic teaching but do not realise that they are in fact averting people from the Truth.

By quoting verses from the Holy Qur'an and statements of Allah's Messenger, peace and blessings of Allah be upon him, we intended to prove that there are individuals who have unsufficient knowledge regarding the proper Islamic teaching.

The resulting consequences can be catastrophic for smaller and wider community.

It is necessary for proper activity and engagement in the area of Islamic da'wah to have wide education and knowledge of this very specific field. Our Exalted Lord has 99 beatiful names (Al-AsmaulHusna), amongst which are mostly names with meanings of mercy, forgiveness and compassion.

Similar to this, Muhammed, peace and blessings of Allah be upon him, used methods based on compassion and mercy in his da'wah. This represents one of the factors which led to sucess in his blessed mission.

We pray and ask our Lord to enrich our souls with the qualities of the most successful teacher, to give us strenght in our da'wah and to make our feet firm on the Right Path-Ameen. 
د. عزت ترزيتش

لحة عن أساليب العمل الدعوي ترزيتر

خلاصة البحث

الهدف الأساسي من هذا البحث الإشارةٌ إلى بعض الأخطاء لدى بعض المسلمين الذين يعتبرون

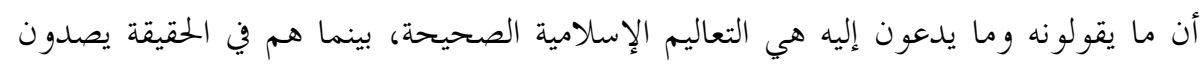

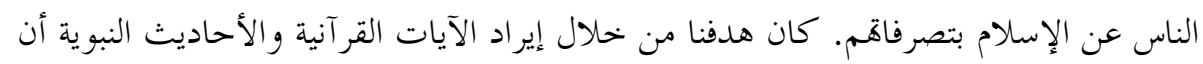

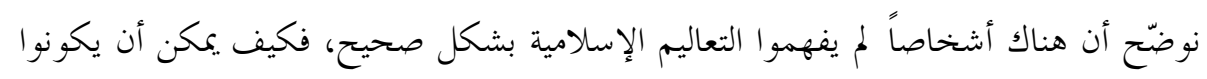

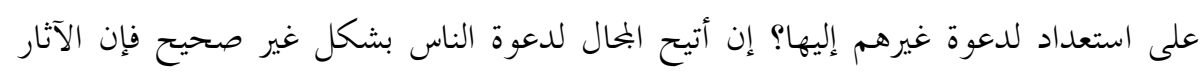

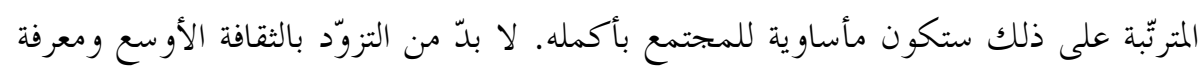

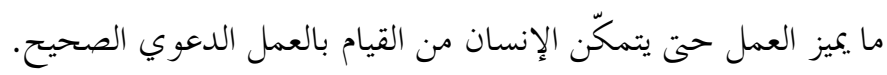

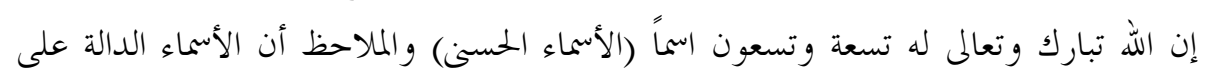
الرأفة والرحمة والمغفرة أكثر عدداً من الصفات الدالة على العقوبة. و وكان البي صلى اللى الله عليه

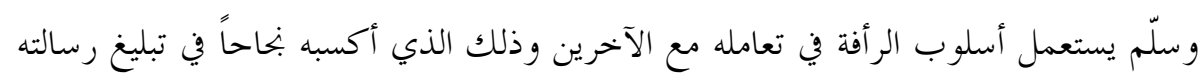
العظيمة.

ندعو الله ونسأله أن يوفقنا حتى نتخلّق ونتحلّى بأخحلاق الداعية الناجح، أن يقوّينا في سبيل ذلك وأن يثبّتنا على الصراط المستقيم. آمين. 